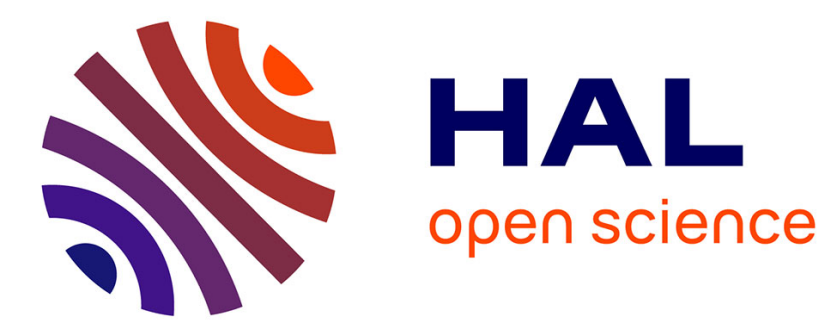

\title{
Synthesis of a novel archaeal tetraether-type lipid containing a diorthoester group as a helper lipid for gene delivery
}

J. Barbeau, N. Belmadi, T. Montier, T. Le Gall, S. Dalençon, L. Lemiègre, T. Benvegnu

\section{To cite this version:}

J. Barbeau, N. Belmadi, T. Montier, T. Le Gall, S. Dalençon, et al.. Synthesis of a novel archaeal tetraether-type lipid containing a diorthoester group as a helper lipid for gene delivery. Tetrahedron Letters, 2016, 57 (27-28), pp.2976-2980. 10.1016/j.tetlet.2016.05.090 . hal-01341581

HAL Id: hal-01341581

https://hal-univ-rennes1.archives-ouvertes.fr/hal-01341581

Submitted on 13 Oct 2016

HAL is a multi-disciplinary open access archive for the deposit and dissemination of scientific research documents, whether they are published or not. The documents may come from teaching and research institutions in France or abroad, or from public or private research centers.
L'archive ouverte pluridisciplinaire HAL, est destinée au dépôt et à la diffusion de documents scientifiques de niveau recherche, publiés ou non, émanant des établissements d'enseignement et de recherche français ou étrangers, des laboratoires publics ou privés. 


\section{Graphical Abstract}

To create your abstract, type over the instructions in the template box below.

Fonts or abstract dimensions should not be changed or altered.

\section{Type the title of your article here}

Authors' names here

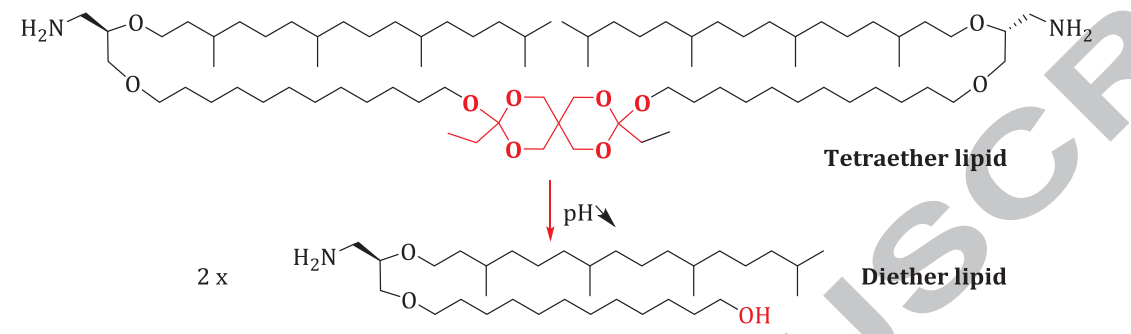




\title{
Synthesis of a novel archaeal tetraether-type lipid containing a diorthoester group as a helper lipid for gene delivery
}

\author{
Julie Barbeau,d, Nawal Belmadi, ${ }^{\mathrm{b}, \mathrm{d}}$, Tristan Montier ${ }^{\mathrm{b}, \mathrm{c}, \mathrm{d}, \mathrm{e}, *}$, Tony Le Gall, ${ }^{\mathrm{b}, \mathrm{d}, \mathrm{d}}$, Sylvain Dalençon ${ }^{\mathrm{a}, \mathrm{d}}$, Loïc \\ Lemiègre $^{\mathrm{a}, \mathrm{c}, \mathrm{d}, *}$, and Thierry Benvegnu ${ }^{\mathrm{a}, \mathrm{c}, \mathrm{d}, *}$ \\ ${ }^{a}$ Ecole Nationale Supérieure de Chimie de Rennes, CNRS, UMR 6226, 11 allée de Beaulieu, CS 50837, 35708 Rennes Cedex 7, France \\ ${ }^{b}$ Unité INSERM 1078, SFR ScInBioS; Université de Bretagne Occidentale, 46 rue Félix Le Dantec, CS51819, 29218 Brest Cedex 02, France \\ ${ }^{c}$ Plateforme SynNanoVect, SFR ScInBioS; Université de Bretagne Occidentale, Brest, France \\ ${ }^{d}$ Université Bretagne et Loire, France \\ érervice de Génétique Moléculaire et d'Histocompatibilité, CHRU de Brest, Hôpital Morvan, 2 avenue du Maréchal Foch, 29609 Brest Cedex, France
}

\section{ARTICLE INFO}

\section{ABSTRACT}

\section{Article history:}

Received

Received in revised form

Accepted

Available online

Keywords:

Archaeal tetraether lipid

Helper lipid

Diorthoester moiety

DNA complexation

Transfection
As an alternative to recombinant virus, synthetic carriers are widely developed for providing efficient and safe DNA delivery. To reach the nucleus where nucleic acids (NA) constructs are transcripted, chemical complexes have to overcome serious cellular traps such as endosomal escape and intracellular trafficking. Here, the design and the multi-step synthesis of a stabilizing tetraether lipid analogue of archaeal counterparts containing a diorthoester moiety in the middle of the bridging chain were described. The key step involved a double coupling reaction between two diether alcohols and a diketene acetal. Under aqueous acidic conditions, the diorthoester function of the tetraether lipid can be hydrolysed to yield two monopolar diether lipids. Applied to gene delivery in association with a cationic lipid, this new helper bipolar tetraether lipid led to lipid-DNA complexes with sizes and potential zeta values depending on the charge ratios (+/-). In addition, preliminary in vitro transfection assays supported the interest of these novel bipolar lipid-based lipoplex formulations compared to standard Lipofectamine-based formulations. 2009 Elsevier Ltd. All rights reserved.

\section{Introduction}

Gene therapy constitutes a promising strategy for the treatment of acquired and inherited diseases but is largely dependent on the efficacy and tolerance of vectors. ${ }^{1-3}$ Due to their relative innocuity and their capacity to be readministered, ${ }^{4,5}$ the design of innovative non-viral delivery systems represents an active field of research. Although significant progresses have been performed - notably in vivo - ${ }^{6}{ }^{6}$ they led to lower transgene expression than viral carriers. Their optimization requires the understanding of the cellular steps encountered and the chemical adaptation of the carriers as well as their fine-tuned formulation combining different molecules with various properties. Indeed, non-viral transfection is actually a particularly delicate process involving several crucial steps: 1) the compaction of NA reducing its size and inducing a protection against DNase, 2) the internalization of the corresponding complexes usually by clathrin- and caveolae-mediated endocytosis, ${ }^{7}$ 3) the endosomal escape of the NA and trafficking towards the nucleus, 4) the transcription and final production of the encoded protein. Among these steps, the escape of the NA from the endosomal compartment into the cytosol is a crucial stage to avoid lysosomal degradation. Different escape mechanisms from the endosome have been proposed for lipoplexes based upon the destabilization of the endosomal membrane, ${ }^{8-10}$ the exchange of cationic lipids with anionic phospholipids normally found on the cytoplasm-facing monolayer of the cell membrane, ${ }^{11}$ and endosomolysis caused by osmotic swelling ${ }^{12-14}$. Smart systems should provide versatile properties for protection and extracellular trafficking and sufficient instability promoting a rapid endosomal escape. The biological evolution of any endosome is known to induce a decrease of $\mathrm{pH}$ which can be used as a stimulus for $\mathrm{pH}$-sensitive delivery systems. ${ }^{15,17}$ Our research group already described the use of stabilizing bipolar lipid for which the structure is based on archaeal lipids (Fig. 1). ${ }^{18,19}$ We recently demonstrated the particular interest of this type of lipids for gene delivery. Tetraether archaeal lipids are known to span lipid membranes reducing the membrane dynamic, which results in a stabilization of the corresponding membranes. The monolayer-forming synthetic Tetraether 2 (Fig. 1) was combined with a monocationic glycine betaine-derived lipid MM18 (Fig. 1) at various molar ratios and administered via systemic or local delivery routes. ${ }^{20}$ Following i.v. injection, MM18-based formulations demonstrated some high transfection efficiency in mice in vivo depending on the Tetraether 2 proportion mixed. Noteworthy, a MM18/Tetraether $\mathbf{2}$ molar ratio of 10/1 was identified as the most efficient for in vivo gene transfection, especially into the lungs. Furthermore, when associated with MM18, this family of archaeal bipolar lipids showed more efficient in vitro gene transfection properties than common DOPE helper lipid. ${ }^{\mathbf{1 9}}$

With the aim of facilitating the endosomal escape step, we designed a novel tetraether helper lipid 3 including a $\mathrm{pH}$ cleavable moiety (Fig. 1). We based the $\mathrm{pH}$-sensitivity function on orthoester moieties that cleave at $\mathrm{pH}$ around $5 .^{21-23}$ Cleavage of an orthoester placed in the middle of the tetraether structure 
Tetrahedron Letters

leads to two monopolar diether-type lipids 9 (Fig.1) removing the stabilizing properties of the bipolar structure and therefore promoting a faster DNA release from the endosomal vesicles. Indeed, when combined with the cationic lipids, monopolar diethers are supposed to exhibit hexagonal phases, ${ }^{24}$ unlike tetraethers which facilitate the formation of lamellar phases. ${ }^{20}$ As a consequence, the change in lipid membrane organization provided by this chemical transformation of tetraethers into diethers, could promote the endosomal release. The present work describes the synthesis of this new diorthoester-based tetraether $\mathbf{3}$ and the preliminary studies related to its efficiency to complex and to deliver plasmid DNA (pDNA) in in vitro assays when this novel helped lipid was combined with cationic lipid MM18.

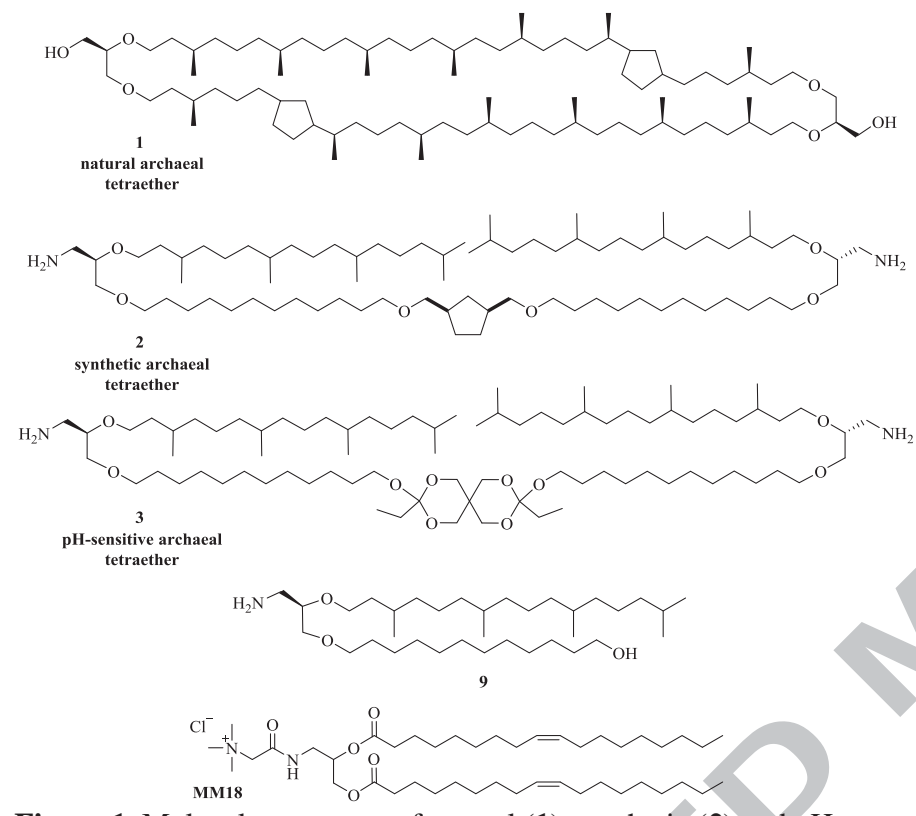

Figure 1. Molecular structure of natural (1), synthetic (2) and $\mathrm{pH}-$ sensitive (3) tetraether lipids, diether lipid (9) and cationic lipid MM18.

\section{Results and discussion}

The synthesis of the diorthoester-based tetraether $\mathbf{3}$ is based on the coupling of two equivalents of the functionalized alcohol 8 with a diketene acetal $\mathbf{1 0}^{\mathbf{2 2 , 2 3 , 2 5}}$ under acidic conditions (Scheme 1). The alcohol 8 was prepared in five steps from the glyceryl derivative $\mathbf{4}$ already described by our research group (in this case a racemic phytol was used instead of a $7 R, 11 R$ form) ${ }^{26}$ In more details, the deprotonation of $\mathbf{4}$ by action of $\mathrm{NaH}$ in THF and subsequent reaction with the bromo- $\omega$-tetrapyranyl ether $5^{27}$ led to the orthogonally protected diol $\mathbf{6}$ in a good yield (81\%). Cleavage of the benzyloxy group by a palladocatalyzed hydrogenolysis afforded the alcohol 7 (82\%), which was activated by mesylation $\left(\mathrm{MsCl} ; \mathrm{Et}_{3} \mathrm{~N}\right)$. The substitution of the mesylate was carried out with sodium azide in the presence of $\mathrm{TBABr}$ leading to the introduction of the azide function on the glyceryl moiety. The methanolysis of the THPO ether under acidic conditions (PTSA, MeOH) finally conduced to the alcohol 8 (98\%), which was therefore ready for the coupling with the diketene acetal. At this stage of the synthesis, we also performed the reduction $\left(\mathrm{PPh}_{3}\right.$ on resin, $\left.\mathrm{H}_{2} \mathrm{O}\right)$ of the azide 8 leading to the corresponding amine $\mathbf{9}$, which served as a reference in the $\mathrm{pH}$ sensitivity and biological assays (Scheme 1). Indeed, monopolar amine $\mathbf{9}$ is the degradation product of tetraether 3 resulting from of the cleavage of the diorthoester function under acidic conditions.

Alcohol 8 was engaged in the double coupling reaction with the diketene acetal 10 (Scheme 2). This step was carried out following procedures described previously. ${ }^{22,23,25}$ The PTSA catalyzed reaction cleanly produced at room temperature the diorthoester 11 (32\%). To avoid extensive purification on silica gel that induced orthoester hydrolysis, we performed the last reduction step in the presence of a resin-supported triphenylphosphine that accomplished the Staudinger's azide reduction in a quantitative yield affording the $\mathrm{pH}$-sensitive tetraether 3.

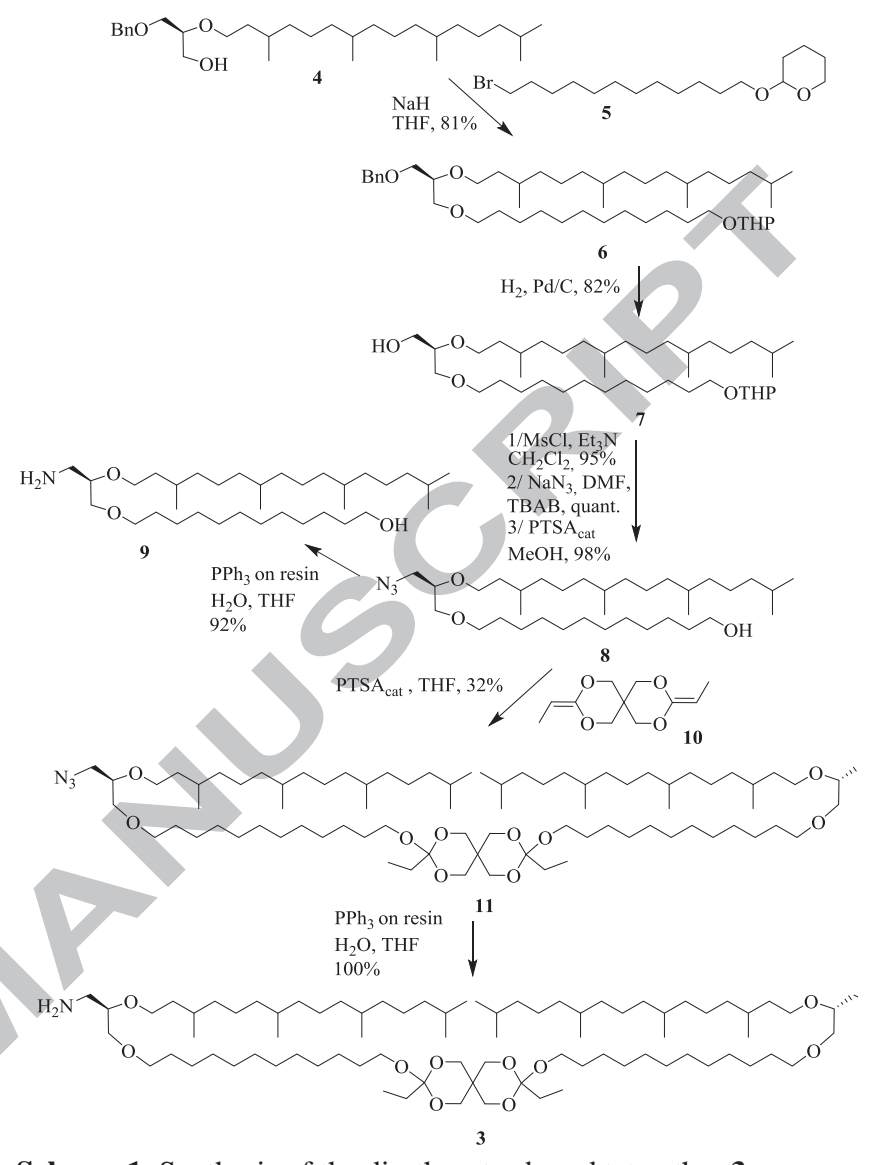

Scheme 1. Synthesis of the diorthoester-based tetraether $\mathbf{3 .}$

As required for DNA complexation, we based our formulations on the cationic lipid MM18 (Fig.1). This original lipid from our research group has already demonstrated efficient gene transfer both in vitro ${ }^{18,28,29}$ and in vivo ${ }^{20}$. In particular, it revealed its higher transfection ability when mixed with helper lipids such a tetraether 2 for instance. ${ }^{\mathbf{1 8}}$ As already shown, Tetraether co-lipids have to be incorporated in a small proportion in the liposomal vesicles in order to exhibit the best in vitro ${ }^{19}$ and in vivo ${ }^{20}$ transfection efficiencies. MM18 was thus combined with either Tetraether $\mathbf{3}$ as a novel helper lipid. The cationic lipid/colipid molar ratio was set at 10/1 (mol:mol) for formulation MM18/3, i.e. at the proportion that led to the best transfection efficiency with the non-cleavable Tetraether $\mathbf{2 .}^{20}$

Hydration of lipid films constituted of a mixture of MM18/3 10:1 permitted to prepare liposomal formulations which were then converted into lipoplexes with various charge ratios (DNA/cationic lipid ratios, i.e. +/- ratios) by mixing these lipid vesicles with DNA aqueous solutions. At low charge ratios ( $C R=1$, excess of negative charges) corresponding to an excess of DNA, as well as at high charge ratios $(\mathrm{CR}=8)$, the lipoplexes were characterised by relatively small sizes $(255 \mathrm{~nm}$ and $734 \mathrm{~nm}$, respectively) with a polydispersity index (PdI) around 0.45 , that were related to the repulsion of highly charged particles (negatively or positively). Indeed, these negative or positive particle surfaces were confirmed by the Zeta potential obtained in both cases $(-33 \mathrm{mV}$ and $+58 \mathrm{mV}$, respectively). At $\mathrm{CR}=4$, the relative neutralisation induced a slight aggregation leading to an increase of the particle sizes $(2890 \mathrm{~nm}$, PdI $=0.46)$. This phenomenon was even more pronounced in the case of quasineutral Zeta potential $(+5 \mathrm{mV}, \mathrm{CR}=2)$ which was characterised by high particle sizes $(3450 \mathrm{~nm}, \mathrm{PdI}=0.82)$. This succession of zones (A-B-C) was already described for lipoplexes. ${ }^{30}$

The MM18/3 liposomes were exposed to acidic conditions at $37^{\circ} \mathrm{C}$ by addition of acetic or trifluoroacetic acid to evaluate their 
pH-sensitivity. After fixing the $\mathrm{pH}$ to $3,4,5$ or 6 , the cleavage was followed by NMR analysis (see supporting information, Fig.S6). Between $\mathrm{pH} 6$ and 5, the $\mathrm{pH}$-sensitive lipid 3 was not cleaved even after 24h. Decreasing the $\mathrm{pH}$ to 4 led to a clear cleavage of lipid within the liposome, after $24 \mathrm{~h}$ about $40 \%$ of lipid were cleaved. At $\mathrm{pH}=3$, the lipid 3 was rapidly cleaved, more than $90 \%$ of cleavage was observed after 5 h of exposure. $\mathrm{pH}$-triggered cleavage in acidic media encouraged us to perform in vitro transfection evaluation of the corresponding lipoplexes. Indeed endosomal compartments reach mild acidic $\mathrm{pH}$ during its maturation. ${ }^{31}$

MM18/3 lipoplexes were evaluated in transfection assays of four different cell lines: two human bronchial epithelial cells, wild type (16HBE 14o-) or $c f$-/- (CFBE), the alveolar type II epithelial cell line (A549), and the HEK 293 cells. The efficacy of both formulations was established for an increasing charge ratio from 1 to 8 in comparison with commercial cationic lipid Lipofectamine ${ }^{\circledR} \quad$ (DOSPA:DOPE (3:1)) and according to routinely used and previously described procedures ${ }^{32}$ (Figure 2). The $\mathrm{pH}$-cleavable formulation MM18/3 gave very interesting results for the four cell-types. In all cases the transfections efficiencies were higher than the lipofectamine ${ }^{\circledR}$ reference. Interestingly, the transfection was very efficient for the two celltypes of interest (16HBE and CFBE). The optimal charge ratio was always 2 and a clear efficiency decrease was observed for $\mathrm{CR}=8$ associated with an slight increase of the cytotoxicity (Fig. 3). Further biological studies are now required to fully evaluate the impact of this tetraether lipid on transfection process, especially when higher amounts of this co-lipid are used in lipoplex formulations. The higher capacity of tetraether $\mathbf{3}$ to fully complex DNA and to exhibit high transfection levels compared with the reference commercial lipofection reagent Lipofectamine ${ }^{\circledR}$, demonstrates a promising potential for its development as an helper lipid for gene delivery systems.

In parallel of the determination of the transfection efficiency, the evaluation of the cytotoxicity induced by the lipoplexes was performed using a chemiluminescent test (see supporting information). The results (Fig. 3) expressed in relative light units (RLU) showed low toxicities except for the higher charge ratio lipoplexes $(\mathrm{CR}=8)$.

\section{Conclusions}

In summary, non-viral gene delivery suffers from insufficient in vivo performances and needs new tools for a better delivery control. The present work described the synthesis of a new type of bipolar lipid that includes an orthoester function in the middle of the bridging chain that can be hydrolyzed upon exposure to acidic conditions. The key step of the synthetic scheme was based on the reaction of a diether lipid containing a free alcohol function at the terminal end of a lipophilic chain, with diketene acetal in the presence of an acidic catalyst. This straightforward approach proved to be an effective way of building symmetrical tetraether lipids containing a central $\mathrm{pH}$-sensitive function. An original formulation based on this novel tetraether lipid promoted promising transfection efficiencies of pulmonary cell-types (16HBE and CFBE). A more complete biological study including in vivo evaluations will be carried out in due course to confirm the interest of such diorthoester-based bipolar lipid in gene delivery and to evaluate more deeply the role of the diorthoester moiety. In particular, the effect of this orthoester-containing bipolar lipid $\mathbf{3}$ on endosomal escape will be investigated in comparison with the corresponding tetraether lipid 2. Proton diffusion within the lipid membrane will be also evaluated through the use of the fluorescent $\mathrm{pH}$ indicator pyranine in order to determine how the protons will get the hydrophobic interior to cleave the orthoester group. Furthermore, various lipid/co-lipid molar ratios will be tested with the aim of optimizing the influence of this novel tetraether by increasing its incorporation into formulations.

\section{Acknowledments}

This work was supported by grants from "Association Française contre les Myopathies" (Evry, France), "Vaincre la Mucoviscidose" (Paris, France) and "Conseil Régional de Bretagne".
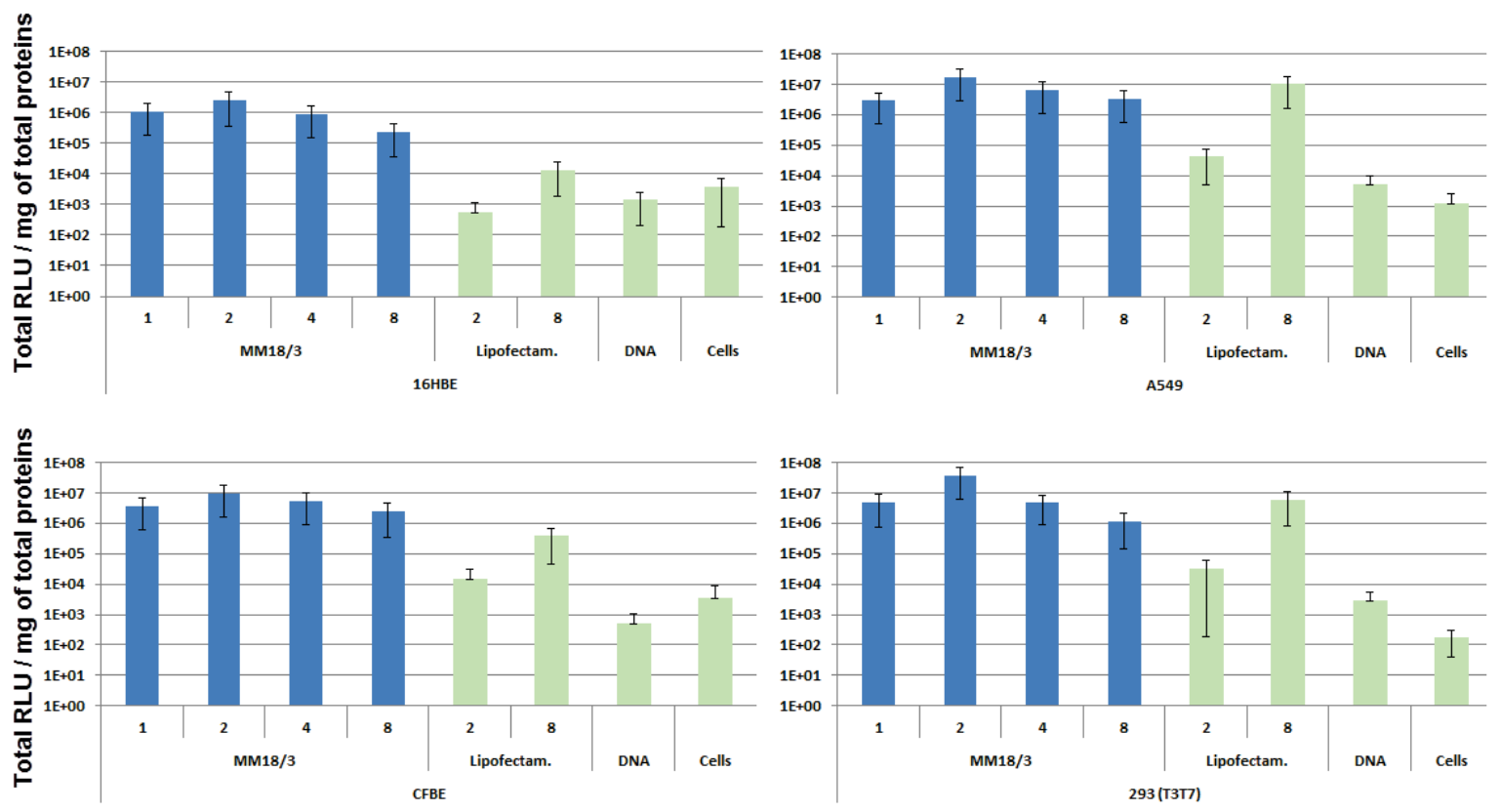

Figure 2. In vitro transfection efficacy of MM18/3 and Lipofectamine (LFM)-based lipoplexes with 16HBE 140-, A549, CFBE 41o- and HEK293 cell lines. Cell lines were transfected with different formulations at various charge ratios. Untransfected cells and naked DNA were used as negative controls. Results are expressed as the Relative Light Units/mg of total proteins obtained with each formulation, reflecting their transfection abilities, as the mean \pm SD of 3 wells. 


\section{Supplementary data}

Supplementary data (all the data, NMR spectra for compounds 6-9, 11 and 3) associated with this article can be found, in the outline version, at http://

\section{References and notes}

1. Montier, T.; Benvegnu, T.; Jaffrès, P. A.; Yaouanc, J. J.; Lehn, P. Curr. Gene Ther. 2008, 8, 296-312.

2. Berchel, M.; Le Gall, T.; Couthon-Gourvès, H.; Haelters, J. P.; Montier, T.; Midoux, P.; Lehn, P.; Jaffrès, P. A. Biochimie 2012, 94, 33-41.

3. Resnier, P.; Montier, T.; Mathieu, V.; Benoit, J. P.; Passirani, C. Biomaterials 2013, 34, 6429-6443.

4. Alton, E. W. F. W.; Armstrong, D. K.; Ashby, D.; Bayfield, K. J.; Bilton, D.; Bloomfield, E. V.; Boyd, A. C.; Brand, J.; Buchan, R.; Calcedo, R.; Carvelli, P.; Chan, M.; Cheng, S. H.; Collie, D. D. S.; Cunningham, S.; Davidson, H. E.;G. Davies, G.; Davies, J. C.; Davies, L. A.; Dewar, M. H. Lancet Respir. Med. 2015, in press, http://dx.doi.org/10.1016/S2213-2600(15)00245-3.

5. Lindberg, M. F.; Le Gall, T.; Carmoy, N.; Berchel, M.; Hyde, S. C.; Gill, D. R.; Jaffrès, P. A.; Lehn, P.; Montier, T. Biomaterials 2015, 49, 1-11.

6. Belmadi, N.; Midoux, P.; Loyer, P.; Passirani, C.; Pichon, C.; Le Gall, T.; Jaffres, P. A.; Lehn, P. Montier, T. Biotechn. J. 2015, in press, DOI: 10.1002/biot.201400841.

7. Rejman, J.; Bragonzi, A.; Conese, M. Mol. Ther. 2005, 12, 468474.

8. Farhood, H.; Serbina, N.; Huang, L. Biochim. Biophys. Acta 1995, 1235, 289-295.

9. Koltover, I.; Salditt, T.; Radler, J. O.; Safinya, C. R. Science 1998, $281,78-81$.

10. Smisterová, J.; Wagenaar, A.; Stuart, M. C. A.; Polushkin, E.; ten Brinke, G.; Hulst, R.; Engberts, J. B. F. N.; Hoehstra, D. J. Biol. Chem. 2001, 276, 47615-47622.

11. Xu, Y.; Szoka, F. C. Jr. Biochemistry 1996, 35, 5616-5623.

12. Haensler, J.; Szoka, F. C. Jr. Bioconjugate Chem. 1993, 4, 372 379.

13. Boussif, O.; Lezoualc'h, F.; Zanta, M. A.; Mergny, M. D.; Scherman, D.; Demeneix, B.; Behr, J. P. Proc. Natl. Acad. Sci. USA 1995, 92, 7297-7301.
14. Behr, J. P. Chimia 1997, 51, 34-36.

15. Knorr, V.; Russ, V.; Allmendinger, L.; Ogris, M.; Wagner, E. Bioconjugate Chem. 2008, 19, 1625-1634.

16. Lee, Y.; Fukushima, S.; Bae, Y.; Hiki, S.; Ishii, T.; Kataoka, K. J. Am. Chem. Soc. 2007, 129, 5362-5363.

17. Masson, C.; Garinot, M.; Mignet, N.; Wetzer, B.; Mailhe, P.; Scherman, D.; Bessodes, M. J. Control. Release 2004, 99, 423434.

18. Lainé, C.; Mornet, E.; Lemiègre, L.; Montier, T.; CammasMarion, S.; Neveu, C.; Carmoy, N. ; Lehn, P.; Benvegnu, T. Chem. Eur. J. 2008, 14, 8330-8340.

19. Réthoré, G.; Montier, T.; Le Gall, T.; Delépine, P.; CammasMarion, S.; Lemiègre, L.; Lehn, P.; Benvegnu, T. Chem. Commun. 2007, 2054-2056.

20. Le Gall, T. ; Barbeau, J.; Barrier, S.; Berchel, M.; Lemiègre, L.; Jeftic, J.; Mériadec, M.; Artzner, F.; Gill, D. R.; Hyde, S. C.; Férec, C.; Lehn, P.; Jaffrès, P. A.; Benvegnu, T.; Montier, T. Mol. Pharm. 2014, 50, 866-868

21. Varkouhi, A. K.; Scholte, M.; Storm, G.; Haisma, H. J. J. Control. Release 2011, 151, 220-228,

22. Guo, X.; Szoka, F. C. Bioconjugate Chem. 2001, 12, 291-300.

23. Huang, Z.; Guo, X.; Li, W.; MacKay, J. A.; Szoka, F. C. J. Am. Chem. Soc. 2006, 128, 60-61.

24. Auzély-Velty, R.; Benvegnu, T.; Plusquellec, D.; Mackenzie, G. ; Haley, J. A. ; Goodby, J. W. Carbohydr. Res. 1998, 314, 65-77.

25. Crivello, J. V.; Malik, R.; Lai, Y. L. J. Polym. Sci., Part A: Polym. Chem. 1996, 34, 3091-3102.

26. Brard, M.; Lainé, C.; Réthoré, G.; Laurent, I.; Neveu, C.; Lemiègre, L; Benvegnu, T. J. Org. Chem. 2007, 72, 8267-8279.

27. Drescher, S.; Meister, A.; Blume, A.; Karlsson, G.; Almgren, M.; Dobner, B. Chem. Eur. J. 2007, 13, 5300-5307.

28. Gilot, D.; Miramon, M. -L.; Benvegnu, T.; Ferrieres, V.; Loreal, O.; Guguen-Guillouzo, C.; Plusquellec, D.; Loyer, P. J. Gene Med. 2002, 4, 415-427.

29. Mornet, E.; Carmoy, N.; Lainé, C.; Lemiègre, L.; Le Gall, T.; Laurent, I.; Marianowski, R.; Férec, C.; Lehn, P.; Benvegnu, T. ; Montier, T. Int. J. Mol. Sci. 2013, 14, 1477-1501.

30. Le Gall, T.; Loizeau, D.; Picquet, E.; Carmoy, N.; Yaouanc, J. -J.; Burel-Deschamps, L.; Delépine, P.; Giamarchi, P.; Jaffrès, P. A.; Lehn, P.; Montier, T. J. Med. Chem. 2010, 53, 1496-1508.

31. Rehman, Z. U.; Zuhorn, I. S.; Hoekstra, D. J. Control. Release 2013, 166, 46-56.

32. Floch, V.; Loisel, S.; Guénin, E.; Hervé, A. C.; Clément, J. C.; Yaouanc, J. J.; des Abbayes, H.; Férec, C. J. Med. Chem., 2000 43, 4617
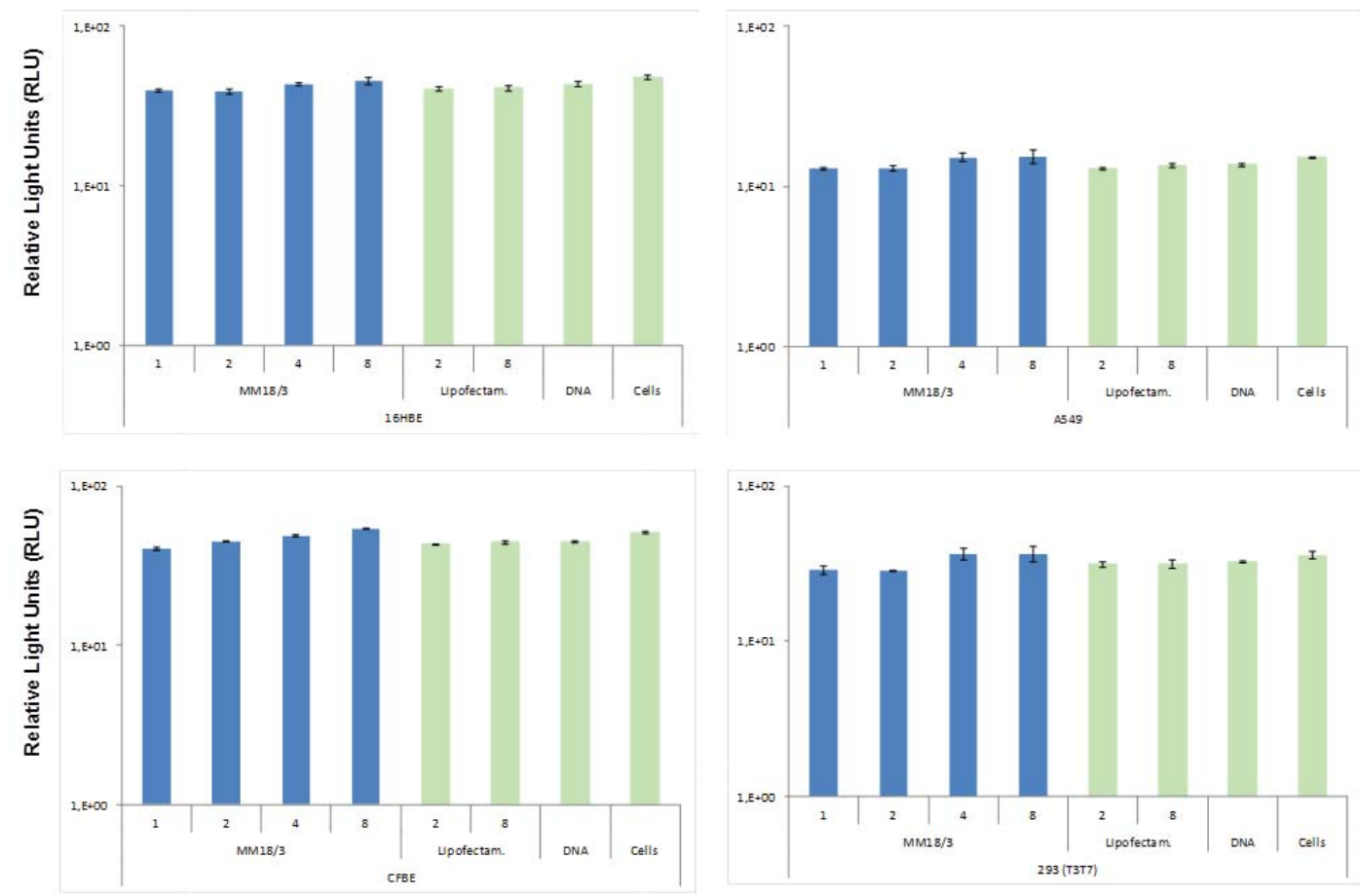

Figure 3. In vitro cytotoxicity of MM18/3 and LFM-based lipoplexes on 16HBE 14o, A549, CFBE 41o- and HEK293 cell lines 3 h after addition of the different formulations onto the cells, the early cytotoxicity induced by the lipoplexes was performed by measuring the adenylate kinase released by the damaged cells, using a chemiluminescent test. The results were expressed in relative light units (RLU) and were conversely proportional to the number of living cells (untreated cells were used as reference). 


\section{Highlights:}

- A novel archaeal tetraether with a pH-sensitive orthoester moiety was synthesized.

- Lipid-DNA complexes based on cationic lipid and tetraether were formulated.

- High in vitro transfection efficiencies and low toxicties were obtained. 